Nevada

Environmental

Restoration

Project

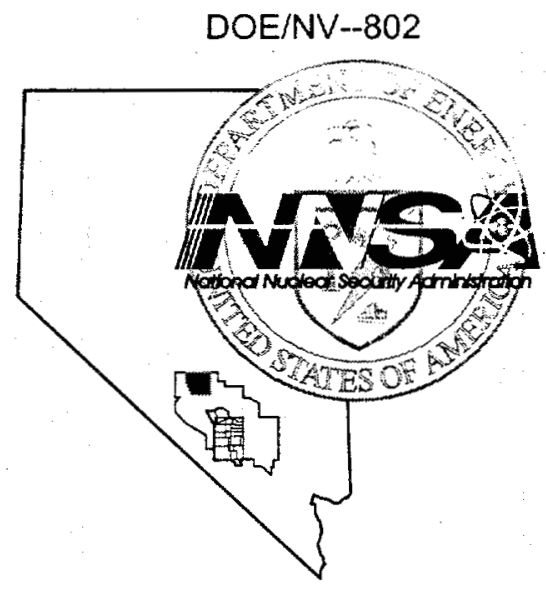

Post-Closure Inspection Report for Corrective Action Unit 427: Area 3 Septic Waste Systems 2 and 6 Tonopah Test Range, Nevada Calendar Year 2001

Controlled Copy No.:

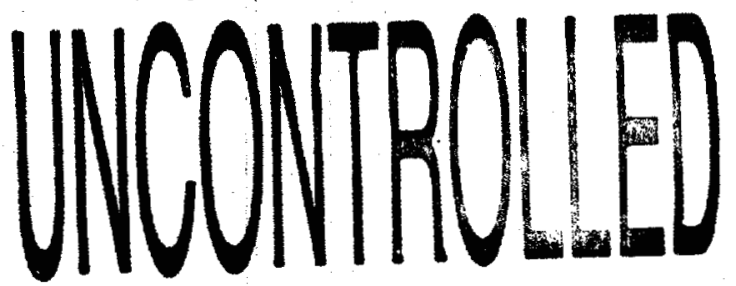

Revision: 0

January 2002

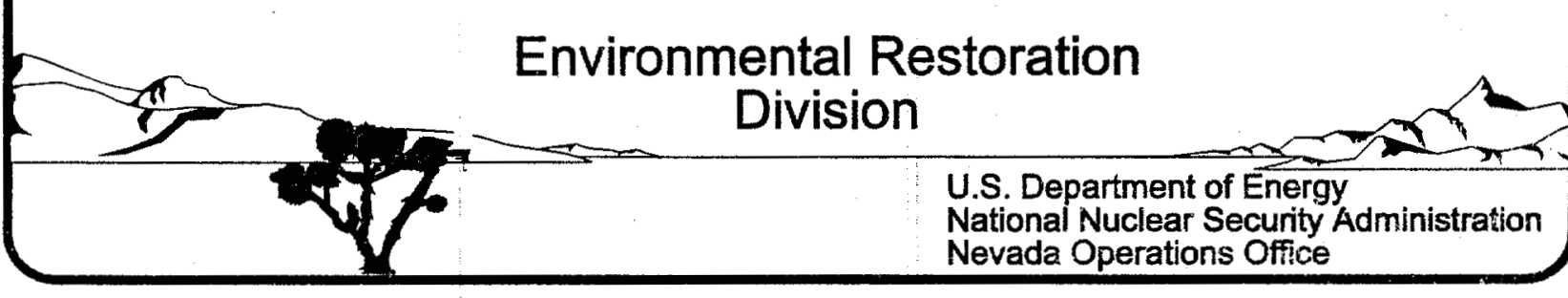




\section{DISCLAIMER STATEMENT}

Reference herein to any specific commercial product, process, or service by trade name, trademark, manufacturer, or otherwise, does not necessarily constitute or imply its endorsement. recommendation, or favoring by the U.S. Government or any agency thereof or its contractors or subcontractors.

\section{AVAILABILITY STATEMENT}

Available for sale to the public from-

U.S. Department of Commerce

National Technical Information Service

5285 Port Royal Road

Springfield, VA 22161-0002

Telephone: 800.553 .6847

Fax: 703.605.6900

E-mail: orders@ntis.fedworld.gov

Online ordering: http://www.ntis.gov/ordering.htm

Available electronically at http://www.doe.gov/bridge

Available for a processing fee to U.S. Department of Energy and its contractors, in paper, from-

U.S. Department of Energy

Office of Scientific and Technical Information

P.O. Box 62

Oak Ridge, TN 37831-0062

Telephone: 865.576 .8401

Fax: 865.576.5728

E-mail: reports@adonis.osti.gov 


\title{
POST-CLOSURE INSPECTION REPORT FOR CORRECTIVE ACTION UNIT 427: AREA 3 SEPTIC WASTE SYSTEMS 2 AND 6 TONOPAH TEST RANGE, NEVADA CALENDAR YEAR 2001
}

\author{
Prepared for \\ U. S. Department of Energy \\ National Nuclear Security Administration \\ Nevada Operations Office \\ Work Performed Under Contract No. \\ DE-AC08-96NV11718
}

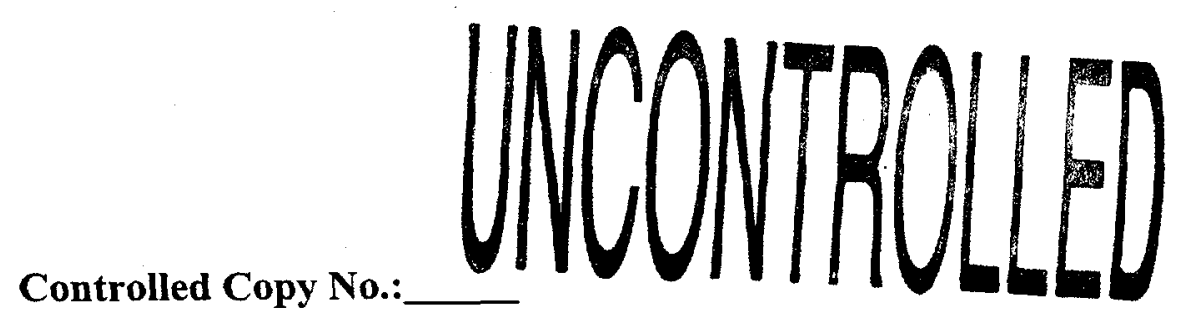

Revision: 0

January 2002 


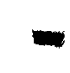




\section{POST-CLOSURE INSPECTION REPORT FOR CORRECTIVE ACTION UNIT 427: AREA 3 SEPTIC WASTE SYSTEMS 2 AND 6 TONOPAH TEST RANGE, NEVADA CALENDAR YEAR 2001}

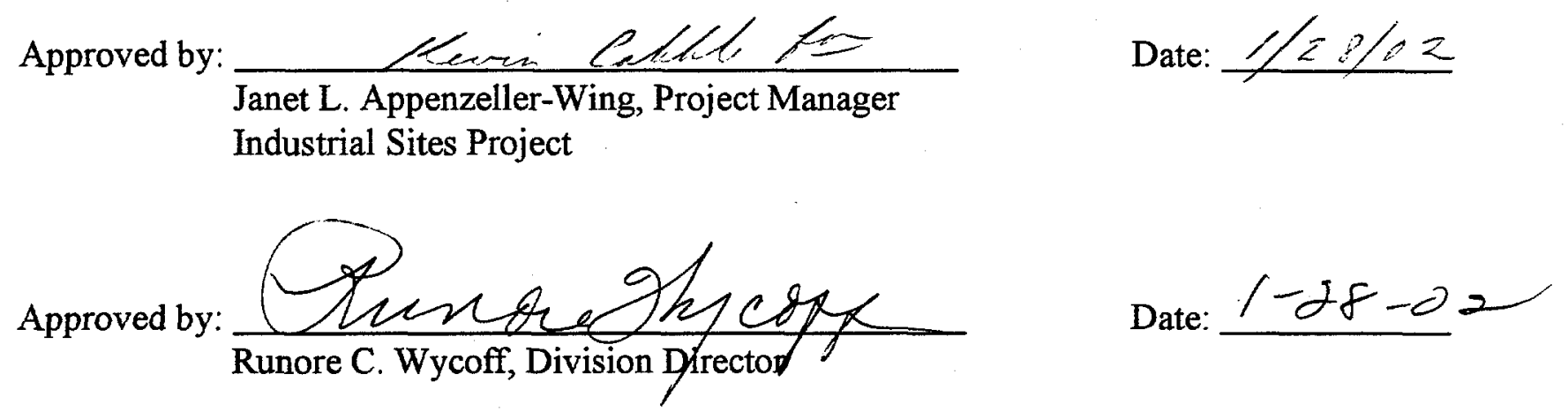


$-$<smiles></smiles>

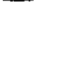

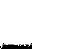

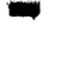

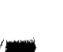

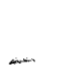

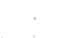

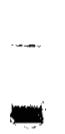

THIS PAGE INTENTIONALLY LEFT BLANK 


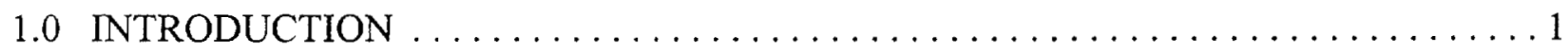

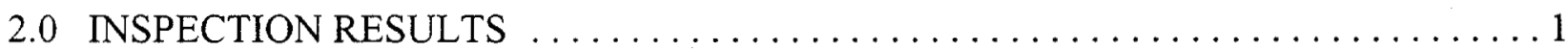

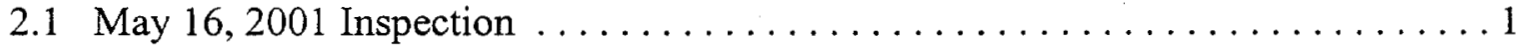

2.2 November 6,2001 Inspection . . . . . . . . . . . . . . . . . . . . 3

3.0 CONCLUSIONS AND RECOMMENDATIONS $\ldots \ldots \ldots \ldots \ldots \ldots \ldots \ldots \ldots$

\section{FIGURES}

FIGURE 1 - AREA 3 SEPTIC WASTE SYSTEMS 2 AND 6 CAU 427 LOCATION MAP . . 2

\section{APPENDICES}

APPENDIX A - INSPECTION CHECKLISTS

APPENDIX B - FIELD NOTES

APPENDIX C - PHOTOGRAPH LOG AND PHOTOGRAPHS

DISTRIBUTION LIST 
Area 3 Septic Waste Systems 3 \& 6

Revision: 0

Date: January 24, 2002

THIS PAGE INTENTIONALLY LEFT BLANK 


\subsection{INTRODUCTION}

Post-closure inspection requirements for the Area 3 Septic Waste Systems 2 and 6 (Corrective Action Unit [CAU] 427) (Figure 1) are described in Closure Report for Corrective Action Unit 427. Area 3 Septic Waste Systems 2 and 6, Tonopah Test Range, Nevada, report number DOE/NV-561, August 1999. The Closure Report (CR) was submitted to the Nevada Division of Environmental Protection (NDEP) on August 16, 1999. The CR (containing the Post-Closure Inspection Plan) was approved by the NDEP on August 27, 1999.

As stated in Section 5.1 of the NDEP-approved CR, the annual Post-Closure inspection at CAU 427 consists of the following:

- Verification of the presence of all leachfield and septic tank below-grade markers.

- Verification that all warning signs are in-place, intact, and readable.

- Visual observation of the soil and asphalt cover for indications of subsidence, erosion, and unauthorized use.

The site inspections were conducted on May 16, 2001, and November 6, 2001. All inspections were made after NDEP approval of the CR, and were conducted in accordance with the Post-Closure Inspection Plan in the NDEP-approved CR. No maintenance or repairs were conducted at the site.

This report includes copies of inspection checklists, photographs, recommendations, and conclusions. Copies of the Post-Closure Inspection Checklists are found in Attachment A, a copy of the field notes is found in Attachment B, and a copy of the inspection photographs is found in Attachments C.

\subsection{INSPECTION RESULTS}

\subsection{May 16, 2001 Inspection}

The first annual inspection was conducted on May 16, 2001. All 20 subsurface metal markers were located at the corners of the Leachfield A (four markers), Leachfield B (four markers); Pre1965 Leachfield (four markers), Abandoned Leachfield (four markers), and Septic Tank 33-5 (four markers) with a metal detector. The four warning signs were observed to be at the as-built locations on Building 03070T (two signs), Building 0367 (one sign), and east of Building 0367 (one sign). No damage to the signs was observed, and all signs were in good readable condition. The soil and asphalt cover areas are located in high traffic areas. Based upon the traffic and yard maintenance activities, no vegetation was observed in the areas. A slight erosion feature/depression was present over Leachfield B and the Abandoned Leachfield. The feature does not effect the integrity of the covers. No other features were observed to indicate 

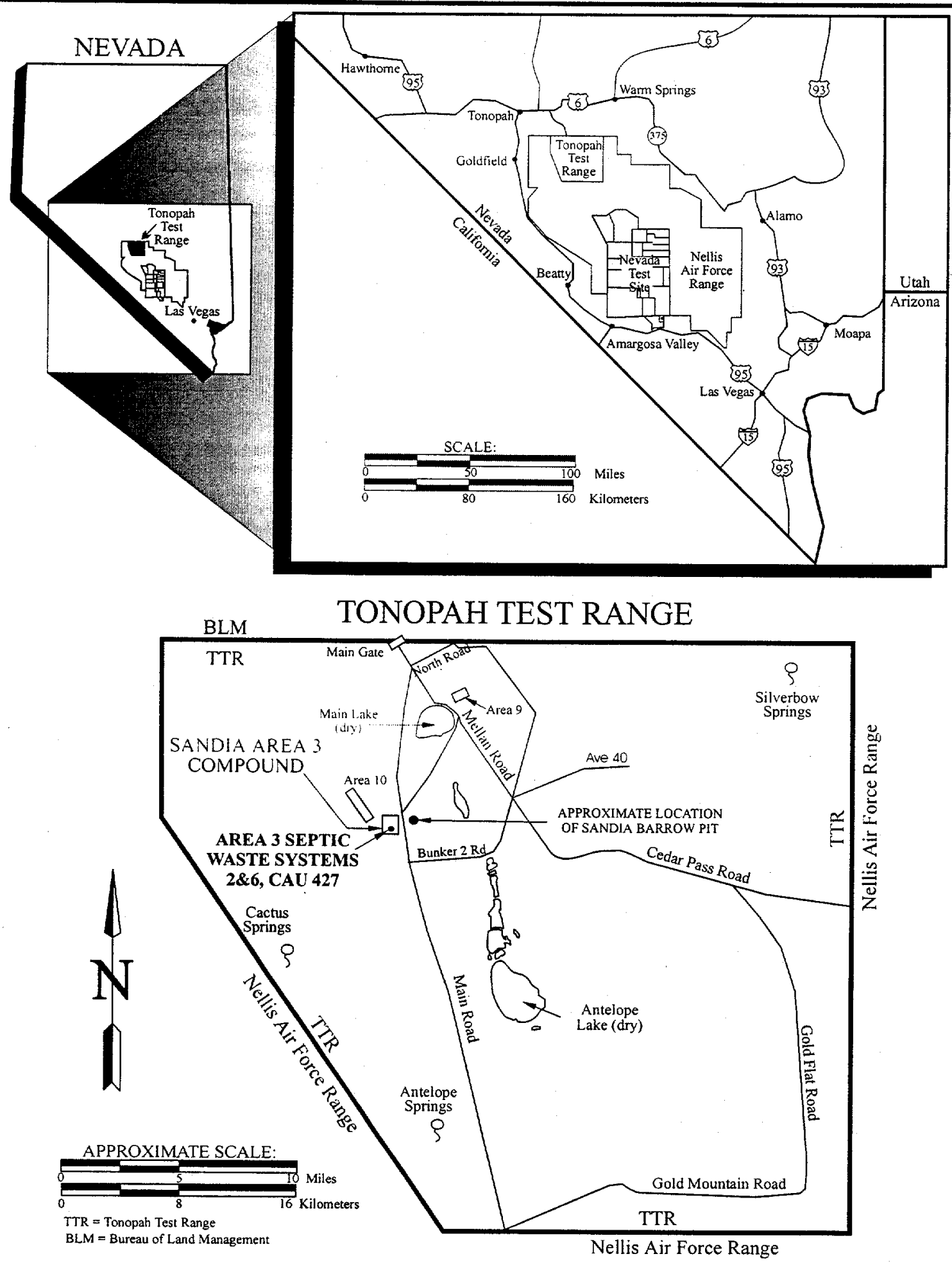

FIGURE 1

AREA 3 SEPTIC WASTE SYSTEMS 2 AND 6 CAU 427 LOCATION MAP 
subsidence, erosion, or unauthorized use (cracks, depressions, erosional channeling, etc.) of the closed sites. The site is in excellent condition.

\subsection{November 6, 2001 Inspection}

The second inspection was conducted on November 6,2001 . Only 8 of the 20 subsurface metal markers were located using a metal detector. The following markers were located using a metal detector:

- $\quad$ Leachfield A - two markers at the west end and one at the east end

- Leachfield B - two markers at the east end

- $\quad$ Pre-1965 Leachfield - no markers

- $\quad$ Abandoned Leachfield - two markers at the west end and one at the east end

- $\quad$ Septic Tank 33-5 - no markers were located

The four warning signs were located as shown on the as-built drawing on Building 03070T (two signs), Building 0367 (one sign), and east of Building 0367 (one sign). No damage to the signs was observed, and all signs were in good readable condition. The soil and asphalt cover areas are located in high traffic areas. Based upon the traffic and yard maintenance activities, no vegetation was observed in the areas. No features were observed to indicate subsidence, erosion, or unauthorized use (cracks, depressions, erosional channeling, etc.) of the closed sites. The site is in excellent condition.

\subsection{CONCLUSIONS AND RECOMMENDATIONS}

All signs were in place. No surface features affecting the integrity of the cover area were observed in the soil and asphalt cover to indicate subsidence, erosion, or unauthorized use. To verify the presence of all subsurface corner markers, it is recommended that during calendar year 2002 the following actions be taken:

- Attempt to locate all subsurface markers using a metal detector.

- If unable to locate with a metal detector, locate markers by surveying from the as-built coordinates (Appendix B of the CR), and expose by digging one foot below ground surface by hand.

- Perform any required maintenance/replacement of the markers before re-burring.

- Mark locations on the surface with survey nails and whiskers and/or paint to aid in locating markers in the future.

Inspection of CAU 427 is recommended for the third year as proposed in the CR. No modifications or repairs to the cover, or changes in the frequency of site inspections, are recommended at this time. 
Area 3 Septic Waste Systems 3 \& 6

Revision: 0

Date: January 24, 2002

THIS PAGE INTENTIONALLY LEFT BLANK 
Post-Closure Inspection Report

CAU No. 427

Area 3 Septic Waste Systems $3 \& 6$

Revision: 0

Date: January 24, 2002

\section{APPENDIX A}

\section{INSPECTION CHECKLISTS}


Post-Closure Inspection Report

CAU No. 427

Area 3 Septic Waste Systems $3 \& 6$

Revision: 0

Date: January 24, 2002

THIS PAGE INTENTIONALLY LEFT BLANK 


\section{POST-CLOSURE INSPECTION CHECKLIST}

CAU 427: Area 3 Septic Waste Systems 2 \& 6. Tonopah Test Range. Nevada

\begin{tabular}{|c|c|}
\hline Date of Last Inspection: $20 \mathrm{Nov} 2000$ & 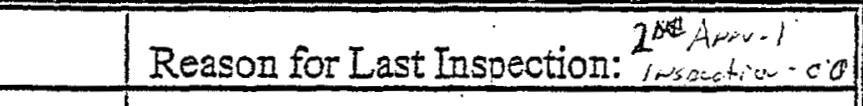 \\
\hline Responsible Agency: " $B N-\varepsilon R$ DOE-NV' & Project Manager: Wayre Johresor \\
\hline \multicolumn{2}{|l|}{ Inspection Date: 16 may 2001} \\
\hline Inspector: Brod Jachisos & Title: Tashi Mavt-S - Organization: BN-ER \\
\hline Assistant Inspector (optional): $\dot{K}_{\text {ev }}$ & Title: Tesk Marase Organization \\
\hline
\end{tabular}

\section{A. GENERAL INSTRUCTIONS}

1. All checklist items must be completed and detailed comments made to document the resuits of the site inspection. The completed checklist is part of the field record of the inspection. Additional pages should be used as necessary so a complete record is made. Attach the additional pages and number all pages upon completion of the inspection.

3. Any checklist line item marked by an inspector in a SHADED BOX, must be fully explained or an

- appropriate reference to previous reports provided. The purpose of this requirement is to provide a written explanation of inspector observations and the inspector's rationale for conclusions and recommendations. Explanations are to be placed on additional attachments and cross-referenced appropriately. Explanations, in addition to the narrative, will take the form of sketches, measurements, and/or annotated site maps.

4. The site inspection is a walking inspection of the entire site including the perimeter and sufficient transects to be able to inspect the entire surface and all features specifically described in this checklist.

5. A standard set of color photographs ( $35 \mathrm{~mm}$, digital, or equivalent) are required to document reportable changes in site conditions between inspections. In addition, all anomalous features or new features (such as changes in adjacent area land use) are to be photographed. A photo log entry will be made for each photograph taken and submitted with the checklist referencing it.

6. This unit will be inspected annually with formal reporting to the Nevada Division of Environmental Protection before completion of the fiscal year in which the inspection occurred. The annual report will include: a narrative summary inciuding recommendations and conclusions; this inspection checklist; inspection field notes; a maintenance record; and photo log (when reportable changes in site conditions are noted).

\begin{tabular}{|c|c|c|c|}
\hline $\begin{array}{l}\text { B. PREPARATION (To be completed prior to } \\
\text { site visit) }\end{array}$ & YES & No & EXPLANATION \\
\hline \multicolumn{4}{|l|}{ 1. Site as-built plans and site base map reviewed. } \\
\hline \multirow{2}{*}{$\begin{array}{l}\text { 2. Previous inspection reports reviewed. } \\
\text { a. Were anomalies or trends detected on previous } \\
\text { inspections? }\end{array}$} & $\checkmark$ & & \\
\hline & & $\checkmark$ & \\
\hline
\end{tabular}




\section{POST-CLOSURE INSPECTION CHECKIIST}

\section{$\mathrm{pg}$ 20f 4}

CAU 427: Area 3 Septic Waste Svstems 2 \& 6. Tonopah Test Range. Nevada

B. PREPARATION (To be completed prior to site visit)

2. b. Was maintenance performed?

3. Site maintenance and repair records reviewed.

a. Has site repair resulted in a change from asbuilt conditions?

b. Are revised as-builts available that reflect repair changes?

C. SITE INSPECTION (To be completed during inspection)

1. Adjacent off-site features.

a. Have there been any changes in use of adjacent areas?

b. Change in surrounding vegetation?

\begin{tabular}{|l|l|l|}
\hline YES & NO & EXPLANATION \\
\hline & $\checkmark$ & \\
\hline & $\checkmark$ & Nom frepaicl \\
\hline & $\checkmark$ & $N / A$ \\
\hline & $V$ & $N A$ \\
\hline YES & NO & EXPLANATION \\
\hline
\end{tabular}

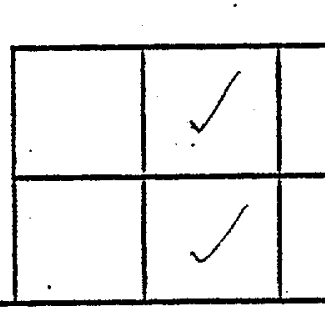

2. Security, signs.

a. Displacement of fences, site markers, boundary markers, or monuments? (disturbed by man or natural processes?) -

b. Have any signs been damaged or removed? Number of signs replaced:

c. Were all subsurface markers detected? (i.e. using a magnatometer or equivalent)

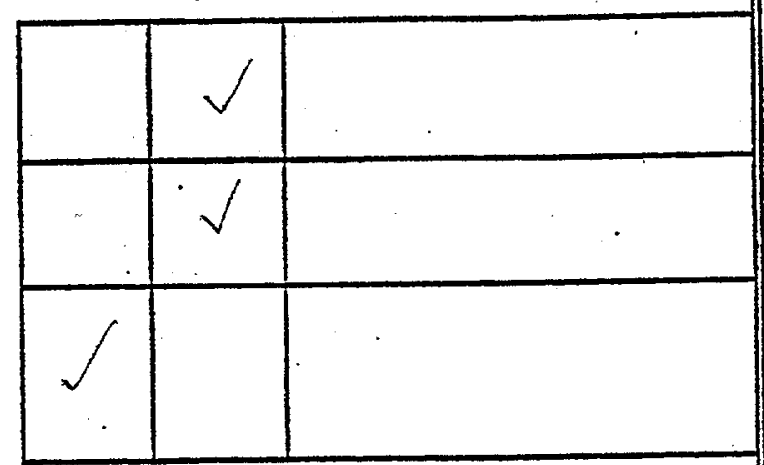




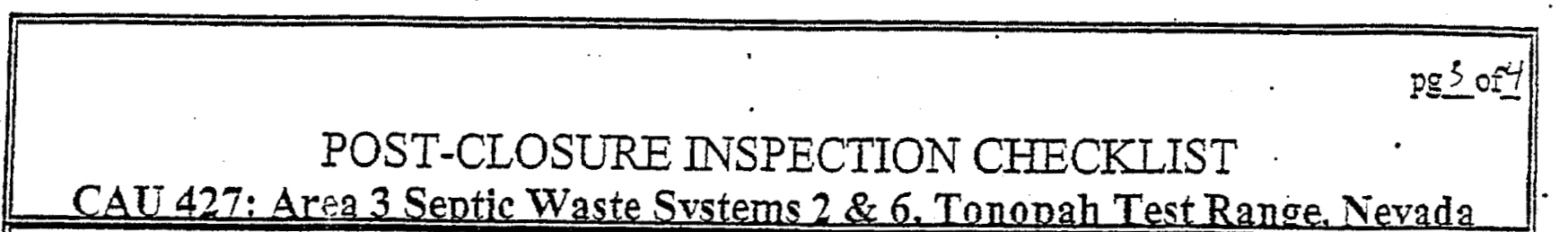

3. Soil/asphalt cover.

a. Is there evidence of setting?

b. Is there cracking?

c. Is there evidence of erosion near the use restriction boundaries?

d. Is there evidence of animal burrowing?

f. Is there vegetation?

g. Do natural processes threaten to integrity of any cover or site marker?

h. Is there evidence suggesting unauthorized excavations have taken place?

h. Other?

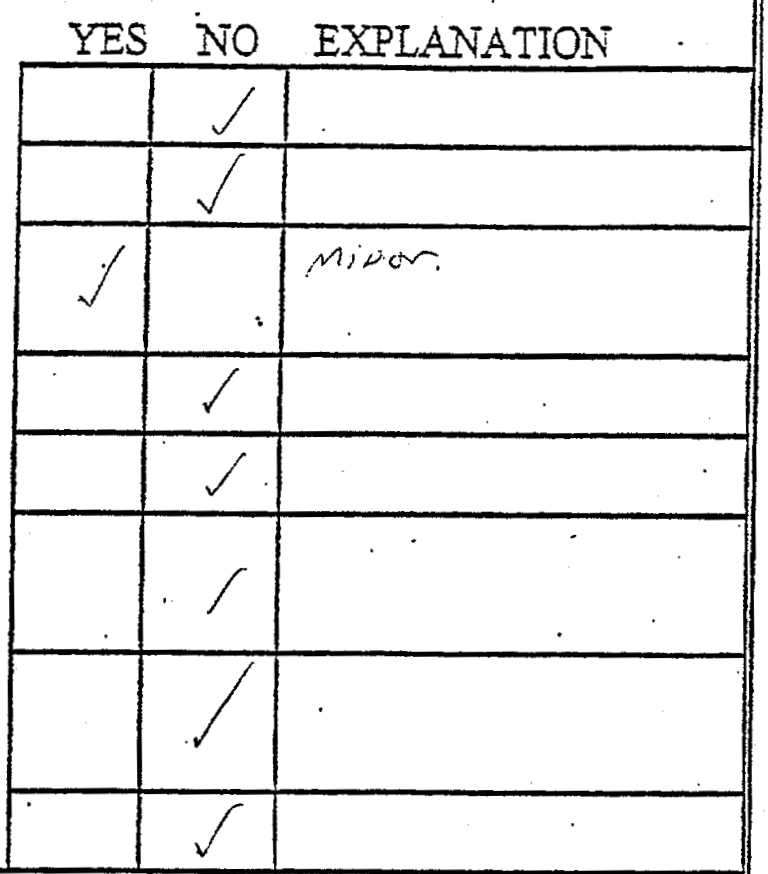

4. Photo Documentation

a. Has a photo log been prepared?

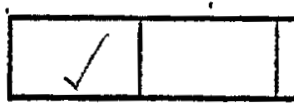

c. Number of photos taken $(7$.

D. FIELD CONCLUSIONS

1. Is there an imminent hazard to the integrity of the unit? (Immediate report required)

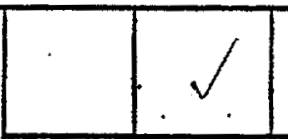

Person/Agency to whom report made:

2. Are more frequent inspections required?

3. Are existing maintenance/repair actions satisfactory?

4. Is other maintenance/repair necessary?

5. Rationale for field conclusions: No charse. sime lest inspection. 


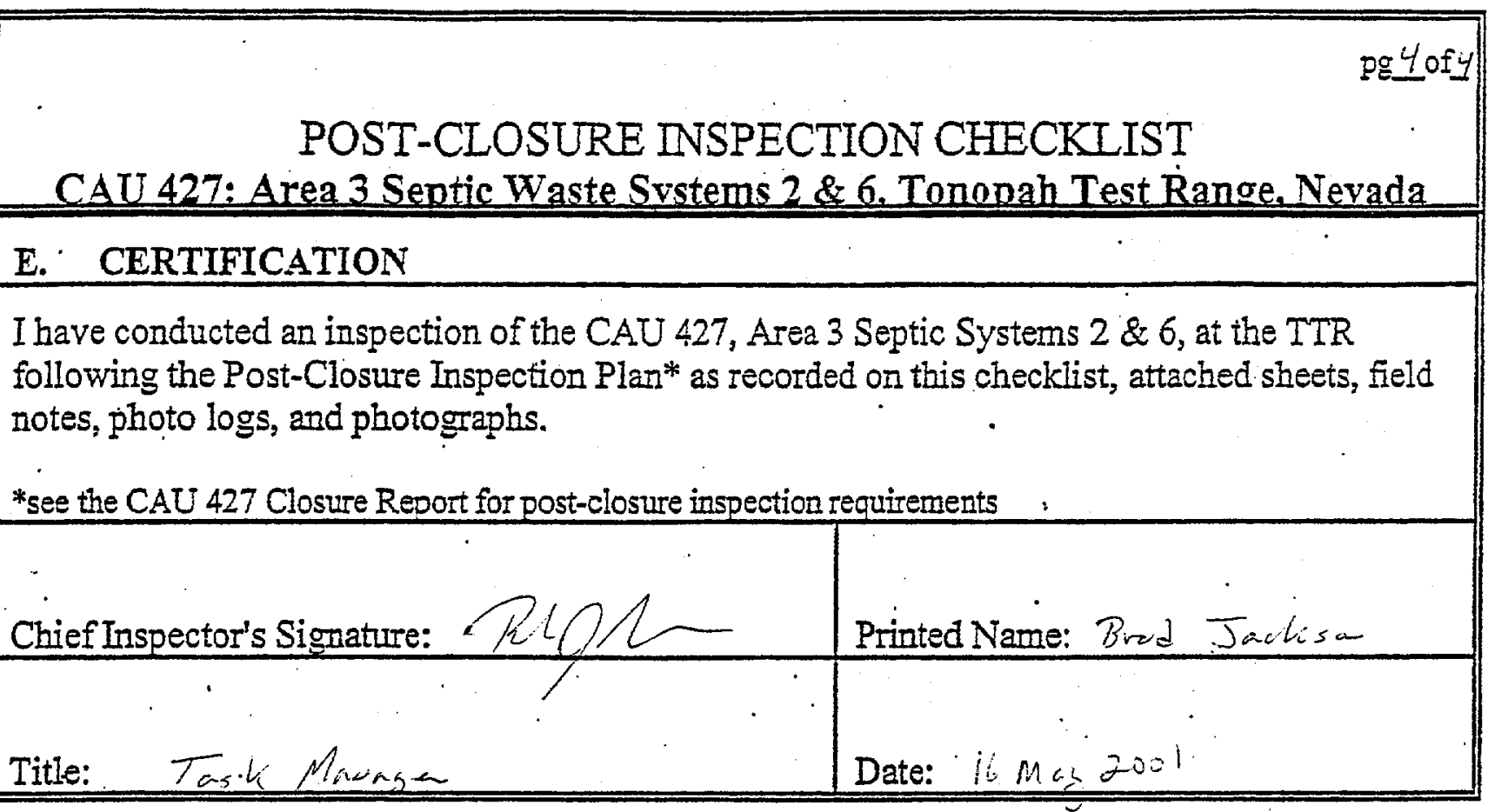




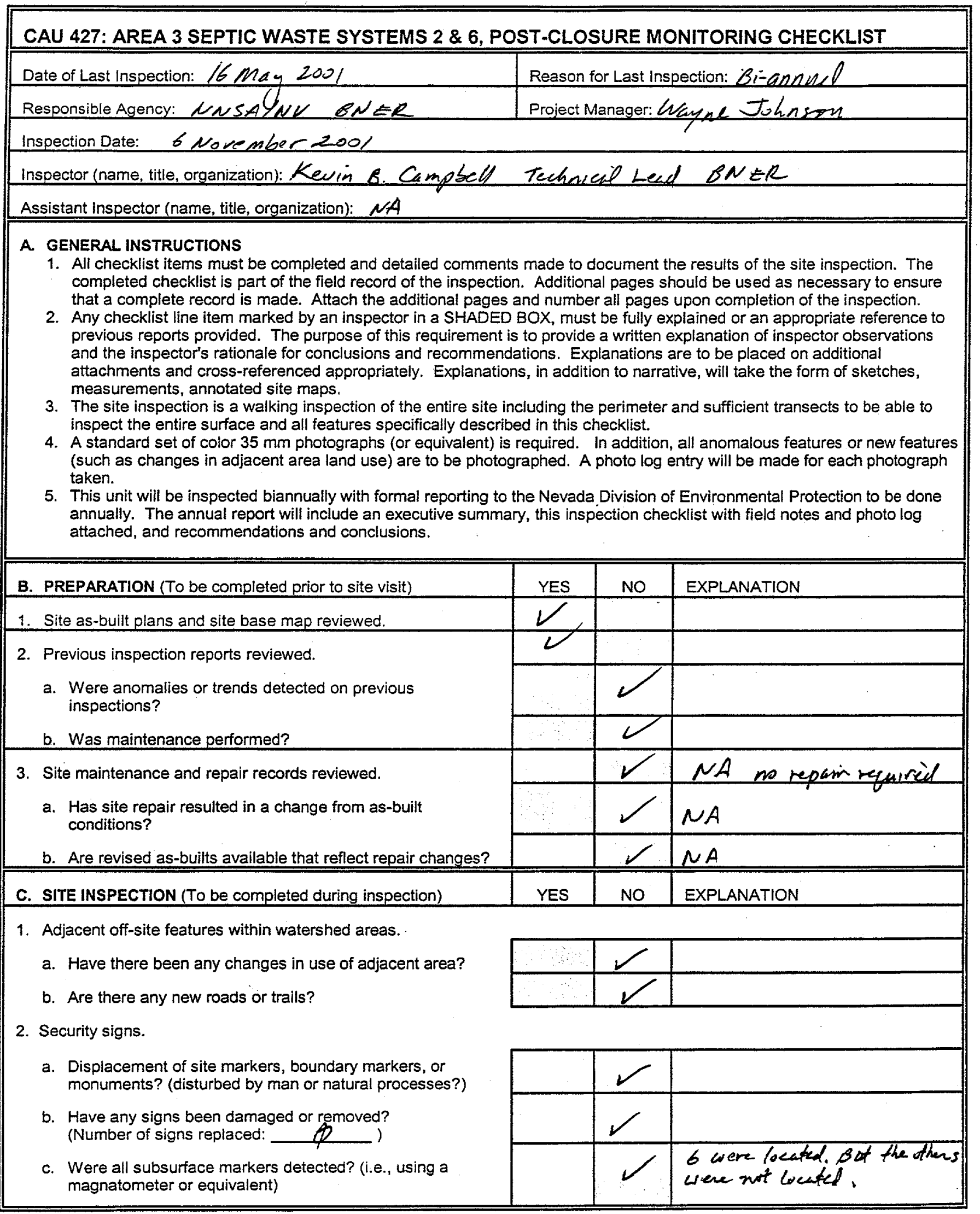




\section{CAU 427: AREA 3 SEPTIC WASTE SYSTEMS $2 \& 6$, POST-CLOSURE MONITORING CHECKLIST}

3. Soillaspharlt cover.

a. Is there evidence of settling?

b. Is there cracking?

c. Is there evidence of erosion near use restriction boundaries?

d. Is there evidence of animal burrowing?

e. Is there vegetation?

f. Do natural processes threaten to integrity of any cover or site marker?

g. Is there evidence suggesting unauthorized excavations have taken place?

e. Other?

\begin{tabular}{|l|c|l|}
\hline YES & NO & EXPLANATION \\
\hline & $\sim$ & \\
\hline & $/$ & \\
\hline & $/$ & \\
\hline & $\checkmark$ & \\
\hline & $\checkmark$ & \\
\hline & $/$ & \\
\hline & & \\
\hline & $\nu$ & \\
\hline & $\checkmark$ & \\
\hline
\end{tabular}

4. Photo Documentation

a. Has a photo log been prepared?

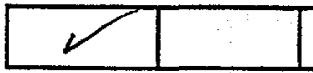

c. Number of photos exposed ( 5 )

\section{FIELD CONCLUSIONS}

1. Is there an imminent hazard to the integrity of the unit? (Immediate report required)

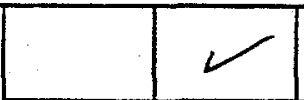

Person/Agency to whom report made:

2. Are more frequent inspections required?

3. Are existing maintenance/repair actions satisfactory?

4. Is other maintenance/repair necessary?

5. Rationale for field conclusions: syis in axcellewt condition. Coukd not coccte

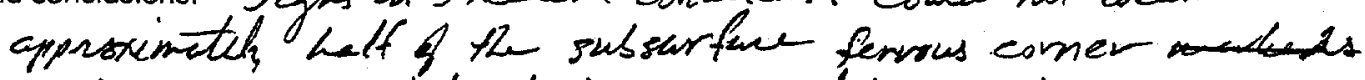
markers asing a metal dekector. Min nead to excevate $21 \mathrm{fl}$ bgs fo becte

\section{E. CERTIFICATION}

I have conducted an inspection of the Cactus Spring Waste Trenches, CAU 426, at the TTR in accordance with the Post-Closure Monitoring Plan (see Closure Report) as recorded on this checklist, attached sheets, field notes, photo logs, and photographs.

\begin{tabular}{|l|l} 
Chief inspector's Signature: Kemi B. Complefl & Printed Name: Kenin B. Campbell \\
\hline & \\
Title: BNER Technical Lead & Date: $11 / 6 / 2001$
\end{tabular}


Post-Closure Inspection Report

CAU No. 427

Area 3 Septic Waste Systems 3 \& 0

Revision: 0

Date: January 24, 2002

APPENDIX B

FIELD NOTES 
Post-Closure Inspection Report

CAU No. 427

Area 3 Septic Waste Systems 3 \& 6

Revision: 0

Date: January 24,2002

THIS PAGE INTENTIONALLY LEFT BLANK 
TITLE

work continued from Page 18
PROJECT NO.

BOOK NO.

19

AU 427 A3 Septic Waste System 2 \& 6

4 posted signs in excellent condition

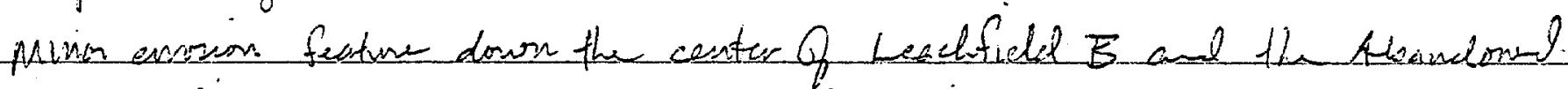

ceachich Feature doe int effect integrity 9 cover.

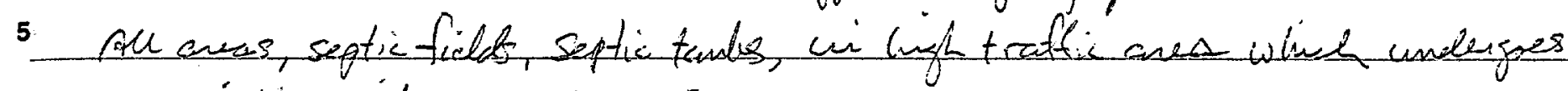
periodic matenames grading.

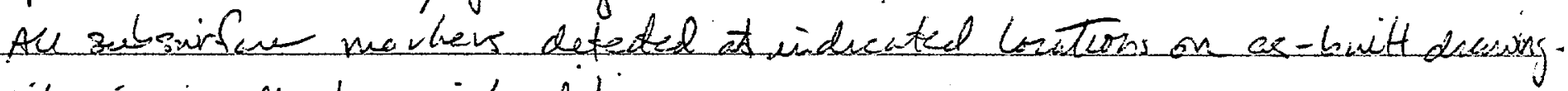
site in excellent repair/ condition.

Least f Line

.

3

)

SCIENTIFIC BWDEAY PAODUCTONS CHICACO 00605 Made in USA

Work continued to Page N/A

5. NATURE

DATE

5116101

CLOSED TO AND UNDERSTOOD BY

DATE

WITNESS

DATE 
PROJECT NO.

25

Work continued from Page 23

BOOK NO.

1410 Start Area 3 septic Waste systems (CAU 427) inspection

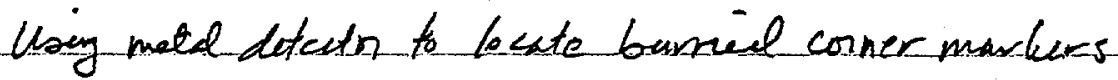

All signs (4 total) in excellent condition.

No vegetation as oren is hevivily trefticed.

5

No sunificunt erasing features.

Site in good condition. Were unable to locate markers for Are 1965-leschfield could rust locate is 1455 Completed Ares 3 Septic Waste Systems (t aU 427) inspection. sabgrach markers

01500 Heading to Castes (CAl l426)

1513 Arrive at cactus

Fence sign gate ai excellent conditrs

small manual burins at base of fencer

vagetiturn very heathy no significant evasion fauns

5 Cover looks en excellent condition

Depart Cactus for Area 3 .

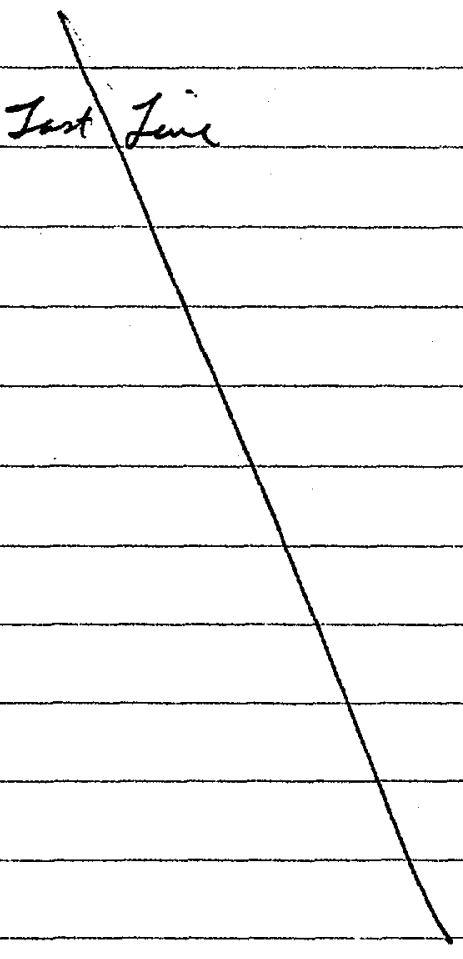

SCIENTIFIC BINDERY PRODUCTIONS CHICAGO 60605 Made in USA

Work continued to Page N IA SIGNATURE

DISCLOSED TO AND UNDERSTOOD BY

Tate witness $\frac{11 / 6 / 0 /}{\text { Date }}$


Post-Clusure Inspection Report

CAU No. 427

Area 3 Septic Waste Systems $3 \& 6$

Revision: 0

Date: January 24, 2002

\section{APPENDIX C}

\section{PHOTOGRAPH LOG AND PHOTOGRAPHS}


Post-Closure Inspection Report

CAU No. 427

Area 3 Septic Waste Systems 3 \& 6

Revision: 0

Date: January 24, 2002 
Date: January 24, 2002

\section{PHOTOGRAPH LOG}

\begin{tabular}{|c|c|l||}
\hline \hline $\begin{array}{c}\text { PHOTO } \\
\text { NUMBER }\end{array}$ & \multicolumn{1}{|c|}{ DATE } & \multicolumn{1}{c|}{ DESCRIPTION } \\
\hline \hline 1 & $05 / 16 / 2001$ & $\begin{array}{l}\text { View north over Septic Tank 33-5 (central area of photograph). } \\
\text { Warning sign on south side of septic tank is visible in center of } \\
\text { the photograph. }\end{array}$ \\
\hline 2 & $05 / 16 / 2001$ & $\begin{array}{l}\text { View to southwest across Pre-1965 Leachfield. and of the } \\
\text { southeast ends of Leachfield A, Leachfield B, and Abandoned } \\
\text { Leachfield. }\end{array}$ \\
\hline 3 & $05 / 16 / 2001$ & $\begin{array}{l}\text { View of the two warning sign on the west and south sides of } \\
\text { Building 0367. }\end{array}$ \\
\hline 4 & $05 / 16 / 2001$ & $\begin{array}{l}\text { View to east of Leachfield B and Abandoned Leachfield. Note } \\
\text { the presence of a slight erosion feature/depression trending along } \\
\text { the axis of Leachfield B and the Abandoned Leachfield. }\end{array}$ \\
\hline 5 & $11 / 06 / 2001$ & $\begin{array}{l}\text { View to east of Abandoned Leachfield and Leachfield B. Note } \\
\text { that the erosion feature/depression present in photograph 4 is no } \\
\text { longer present; the area has been regraded. }\end{array}$ \\
\hline 6 & $11 / 06 / 2001$ & View to southeast of Leachfield B and Abandoned Leachfield. \\
\hline 7 & $11 / 06 / 2001$ & View of warning sign posted on the west side of Building 0367. \\
\hline 8 & $11 / 06 / 2001$ & View north of Pre-1965 Leachfield. \\
\hline
\end{tabular}


Area 3 Septic Waste Systems 3 \& 0

Revision: 0

Date: January 24, 2002 



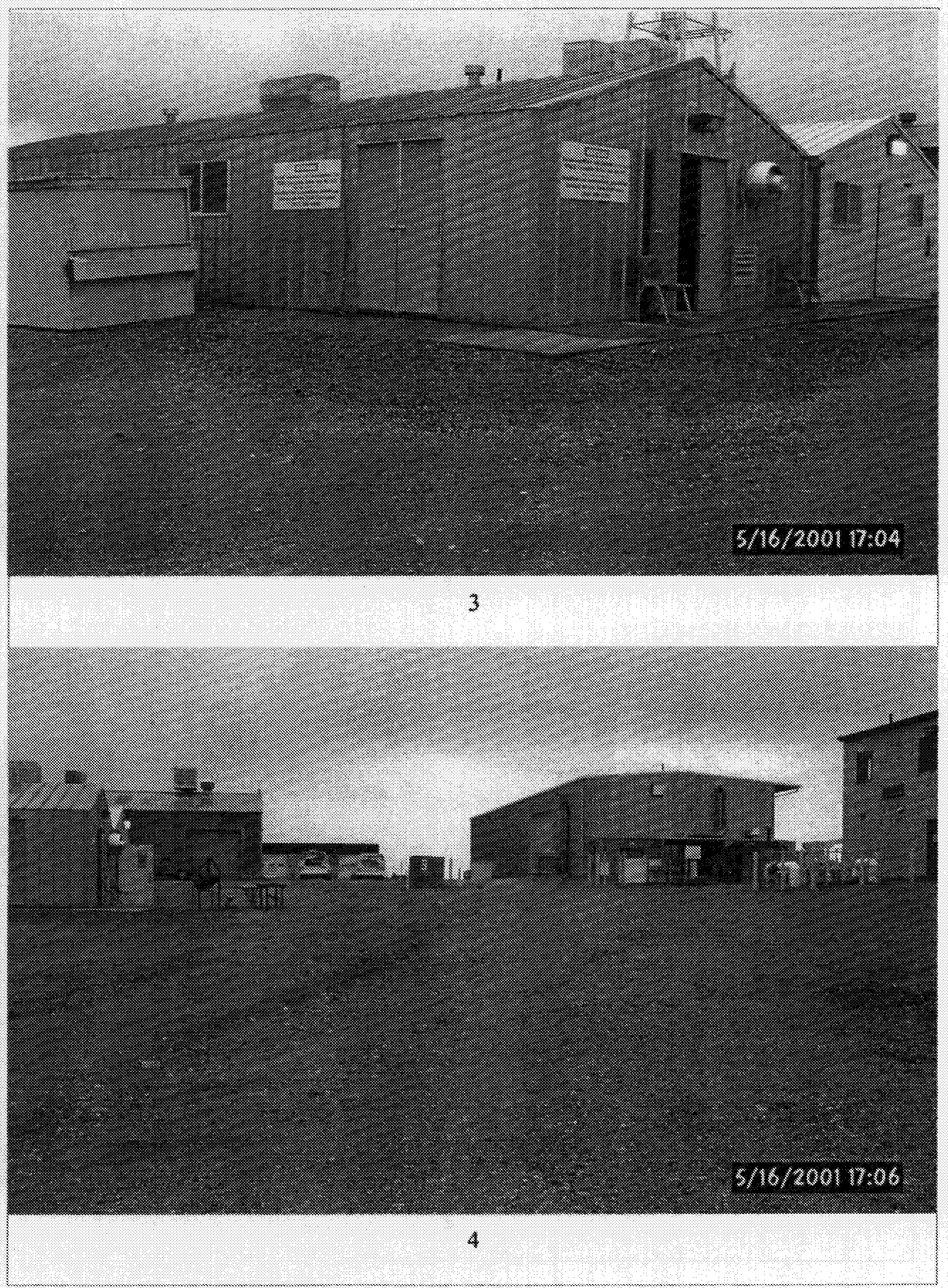




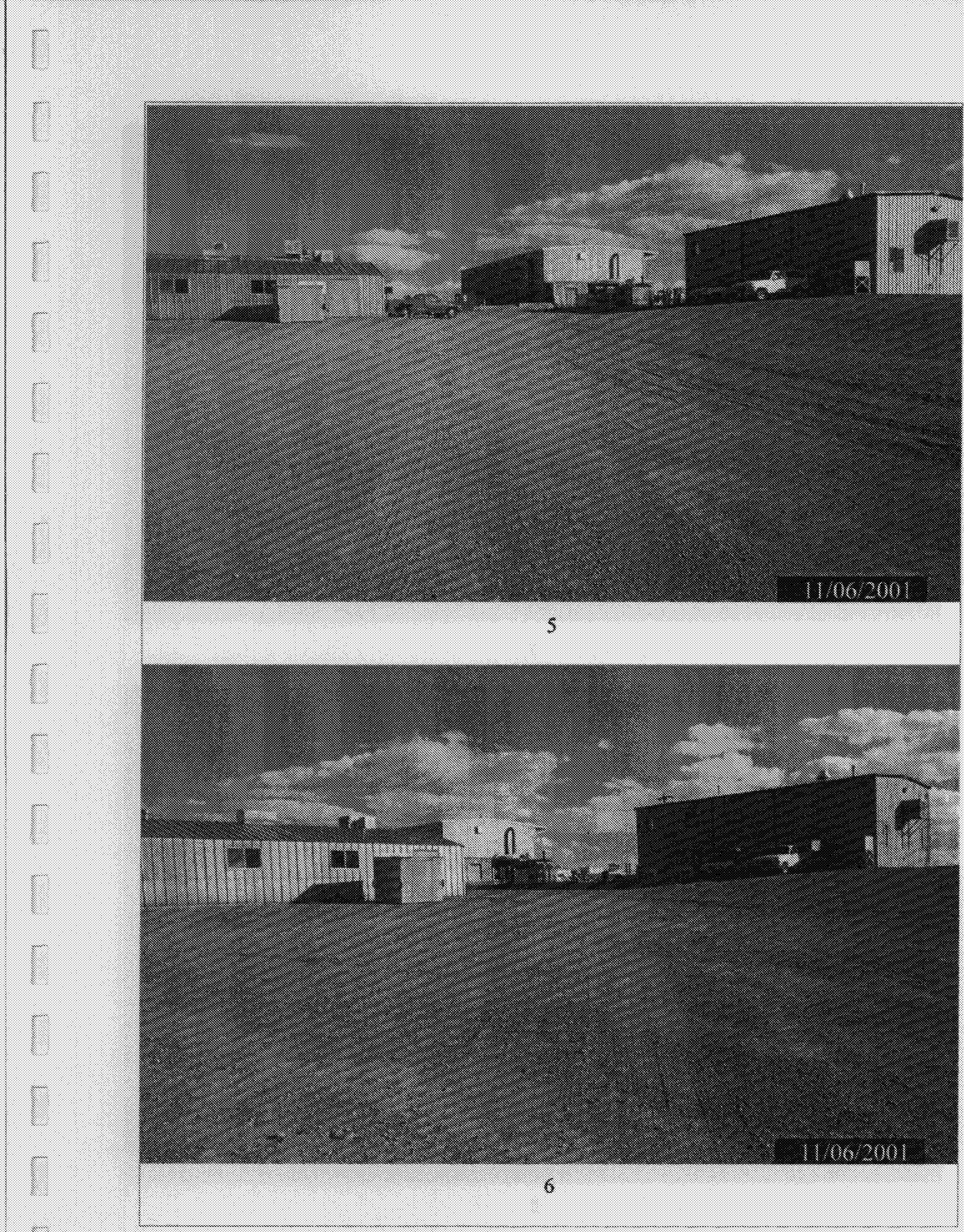




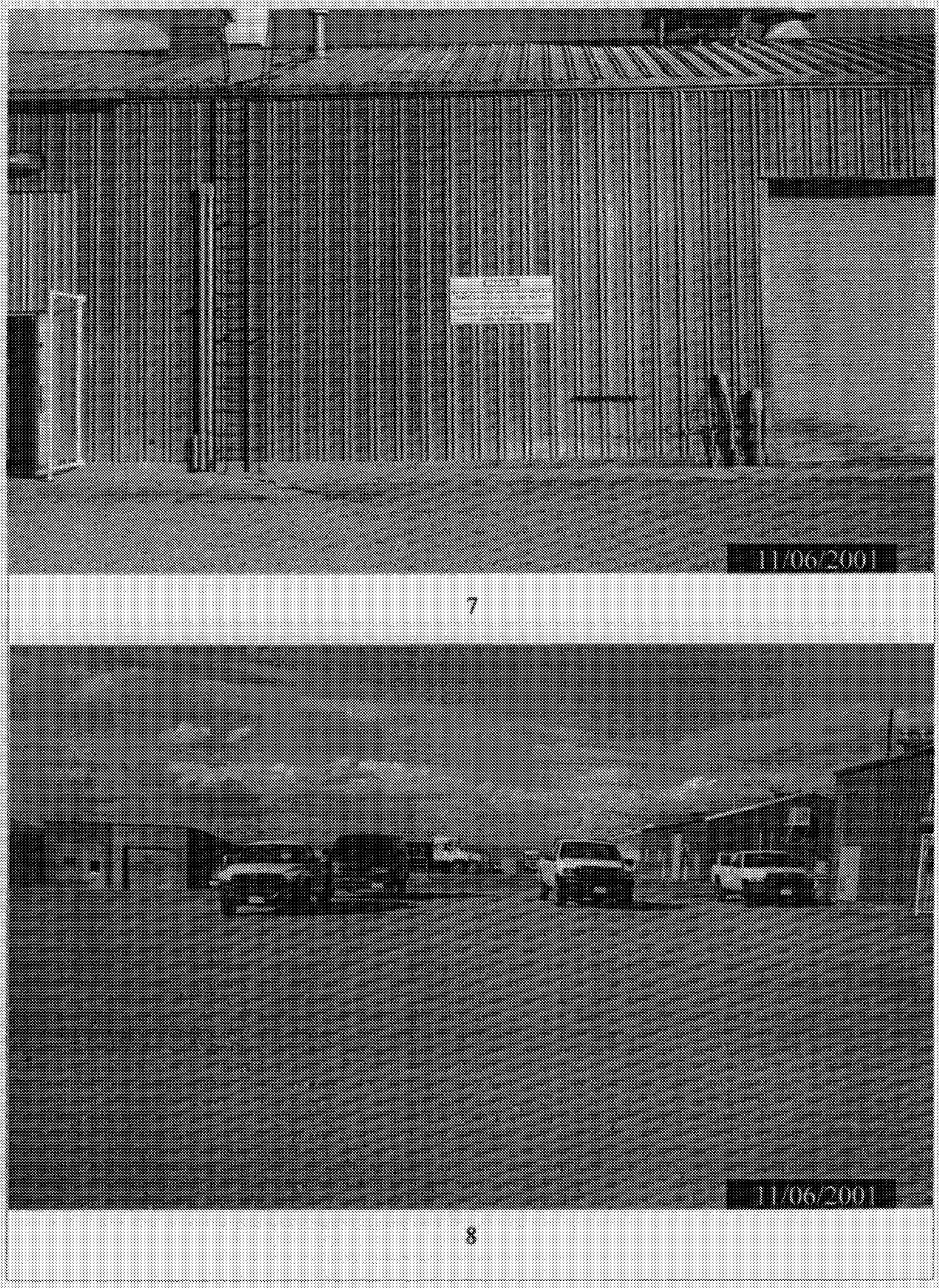


Post-Closure Inspection Report

CAU No. 427

Area 3 Septic Waste Systems $3 \& 6$

Revision: 0

Date: January 24, 2002

DISTRIBUTION LIST 
Area 3 Septic Waste Systems 3 \& 6

Revision: 0

Date: January 24, 2002

THIS PAGE INTENTIONALLY LEFT BLANK 


\section{DISTRIBUTION LIST}

*Provide copy of initial distribution of Revision 0; remainder of list gets Revision 0 if approved without changes. The entire list receives Revision 1, if issued.

\section{Nevada Department of Environmental Protection}

Paul Liebendorfer

2 (Controlled)*

Bureau of Federal Facilities

Division of Environmental Protection

333 W. Nye Lane, Room 138

Carson City, NV 89706-0866

Supervisor, Las Vegas Office

1 (Controlled)*

Bureau of Federal Facilities

Division of Environmental Protection

$555 \mathrm{E}$. Washington, Suite 4300

Las Vegas, NV 89010-1043

\section{U.S. Department of Energy}

Janet Appenzeller-Wing

1 (Uncontrolled)*

Project Manager

Environmental Restoration Division

U.S. Department of Energy

National Nuclear Security Administration

Nevada Operations Office

P.O. Box $98518 \mathrm{M} / \mathrm{S} 505$

Las Vegas, NV 89193-8518

Kevin Cabble

1 (Uncontrolled)*

Environmental Restoration Division

U.S. Department of Energy

National Nuclear.Security Administration

Nevada Operations Office

P.O. Box $98518 \mathrm{M} / \mathrm{S} 505$

Las Vegas, NV 89193-8518

Sabrina Lawrence

1 (Controlled)*

Environmental Restoration Division

U.S. Department of Energy

National Nuclear Security Administration

Nevada Operations Office

P.O. Box $98518 \mathrm{M} / \mathrm{S} 505$

Las Vegas, NV 89193-8518 


\section{DISTRIBUTION LIST (Continued)}

\section{U.S. Department of Energy (continued)}

U.S. Department of Energy

1 (electronic copy)

Office of Scientific and Technical Information

P.O. Box 62

Oak.Ridge, TN 37831-0062

U.S. Department of Energy

National Nuclear Security Administration

1 (Controlled) \&

Nevada Operations Office

Public Reading Facility

P.O. Box $98521 \mathrm{M} / \mathrm{S}$ NLV040

Las Vegas, NV 89193-8521

U.S. Department of Energy

1 (Uncontrolled)

National Nuclear Security Administration

Nevada Operations Office

Technical Information Resource Center

P.O. Box $98521 \mathrm{M} / \mathrm{S} 505$

Las Vegas, NV 89193-8521

\section{Bechtel Nevada}

Correspondence Control

1 (Uncontrolled)*

Bechtel Nevada

P.O. Box $98521 \mathrm{M} / \mathrm{S}$ NLV008

Las Vegas, NV 89193-8521

Environmental Management Library

1 (Uncontrolled)

Bechtel Nevada

P.O. Box 98521 N/S NLV080

Las Vegas, NV 89193-8521

Kevin Campbell

1 (Uncontrolled)*

Bechtel Nevada

P.O. Box $98521 \mathrm{M} / \mathrm{S}$ NTS306

Las Vegas, NV 89193-8521

Ann Heidema

1 (Uncontrolled)*

Bechtel Nevada

P.O. Box $98521 \mathrm{M} / \mathrm{S}$ NLV022

Las Vegas, NV 89193-8521

1 (Uncontrolled) 


\section{DISTRIBUTION LIST (Continued)}

\section{Bechtel Nevada (continued)}

Ronald Jackson

1 (Uncontrolled)* $^{*}$

Bechtel Nevada

P.O. Box $98521 \mathrm{M} / \mathrm{S}$ NTS306

Las Vegas, NV 89193-8521

Wayne Johnson

1 (Uncontrolled)*

Bechtel Nevada

P.O. Box $98521 \mathrm{M} / \mathrm{S}$ NTS306

Las Vegas, NV 89193-8521

Steve Nacht

1 (Uncontrolled)*

Bechtel Nevada

P.O. Box $98521 \mathrm{M} / \mathrm{S}$ NTS306

Las Vegas, NV 89193-8521

\section{IT Corporation}

Lynn Kidman

1 (Uncontrolled)*

IT Corporation

P.O. Box $93838 \mathrm{M} / \mathrm{S} 439$

Las Vegas, NV 89193-8521

Garry Romano

1 (Controlled)

IT FFACO Support Office

IT Corporation

P.O. Box $93838 \mathrm{M} / \mathrm{S} 439$

Las Vegas, NV 89193-8521

\section{State Of Nevada}

Manager, Northern Nevada

1 (Controlled) \&

FFACO Public Reading Facility

1 (Uncontrolled)

Nevada State Library and Archives Federal Publications

100 North Stewart Street

Carson City, NV 89701-4285 